\title{
多階層イオン輸送モデルによる 内耳蝸牛のイオン・電位環境の統合的理解
}

任 書晃 ${ }^{1)}$, 吉田 崇正 ${ }^{1,2)}$, 村上 慎吾 ${ }^{3)}$, 上塚 学 ${ }^{1,4}$, 緒方 元気 ${ }^{1)}$, 倉智 嘉久 ${ }^{3)}$, 日比野 浩 ${ }^{1)}$

要約 : 空気の振動である音は, 内耳螖牛に存在する 音の感覚細胞である有毛細胞を振動させる。この時, 有毛細胞の毛に存在するイオンチャネルが開口し, 常時 $+80 \mathrm{mV}$ を示す特殊な内リンパ液からイオンが流 入する。この「内リンパ液高電位」は, 有毛細胞の興 奮に不可欠であり, 螖牛側壁の血管条が成立させる. $\mathrm{Na}^{+}, \mathrm{K}^{+}, 2 \mathrm{Cl}^{-}$共輸送体 ( $\mathrm{NKCC}$ ) $\mathrm{Na}^{+}, \mathrm{K}^{+}$-ATPase の 阻害薬は, 内リンパ液高電位を低下させることで, 薬剤 性難聴を惹起することが報告されているが, その電位 低下のメカニズムは明らかにされていなかった。我々 はこれまでに，血管条に発現する $\mathrm{NKCC} と \mathrm{Na}^{+}, \mathrm{K}^{+}$ATPase が制御する内リンパ液高電位成立機構を電気 生理学的手法により示し, さらに蝸牛内の多階層イオ ン輸送モデル「Nin-Hibino-Kurachi (NHK) model」の 構築とコンピュータシミュレーションによって, 阻害 薬を経動脈的に投与した時に起こる内リンパ液高電 位低下のメカニズムを説明した，血管条に隣接し，そ の一部と一体化しているらせん勒帯を構成する線維 細胞にも, $\mathrm{NKCC} と \mathrm{Na}^{+}, \mathrm{K}^{+}$-ATPase が発現している ことが知られているが, 薬剤性難聴時のこれらの関与 は不明である。近年我々は, らせん勒帯ではおもに $\mathrm{Na}^{+}, \mathrm{K}^{+}$-ATPase が, $\mathrm{K}^{+}$輸送と $\mathrm{K}^{+}$濃度バランスに寄与 すること, そしてNKCC はほとんど機能していないこ とを明らかにした，これらに基づいて，NHK モデル を改訂した。 今後シミュレーションを行うことにより， 輸送体阻害薬の経動脈投与の実験結果を正確に再現す ることが期待される.

\section{1.はじめに}

「内耳蝸牛」は, 音の受容のため高度に分化した器官 である．蝸牛は内・外二種類の異なるリンパ液で満た されている. 外界から内耳蝸牛に達した音は, 基底板 を振動させる (図 $1 \mathrm{~A}$ ). 基底板上の有毛細胞は, 音の 一次受容器であり, 基底側膜を通常の細胞外液である 外リンパ液に, 感覚毛を有する頂上膜を内リンパ液に 浸す.内リンパ液は, $150 \mathrm{mM}$ の高カリウム $\left(\mathrm{K}^{+}\right)$濃 度と $+80 \mathrm{mV}$ の高電位 (endocochlear potential : EP) を示す (1). 音刺激による基底板の振動により感覚毛 が屈曲すると, 内リンパ液の $\mathrm{K}^{+}$イオンは感覚毛頂部 の陽イオンチャネルの開口を介して有毛細胞へ流入し, 細胞を興奮させる。これが音伝達の端緒となり, 音の 機械的刺激は電気信号に変換され, 脳へ伝えられる. 内リンパ液高電位は, 有毛細胞体との間に大きな電位 差を作ることで $\mathrm{K}^{+}$イオン流入を増幅し, 有毛細胞の 鋭敏性を保っている。この電位の消失により難聴が惹 起される. 有毛細胞に流入した $\mathrm{K}^{+}$イオンは, 基底側 膜の $\mathrm{K}^{+}$チャネルを通じて外リンパ液へ放出され, 上 皮組織である血管条によって内リンパ液へ循環すると されている.このイオン輸送システム「 $\mathrm{K}^{+}$循環」は, 内リンパ液高電位を維持する機構である.

以前より，この機構は螖牛側壁の組織である「血管 条」が駆動する $\mathrm{K}^{+}$イオン輸送に立脚すると考えられ てきた（図 1A）。血管条は, 辺縁細胞・中間細胞・基 底細胞の 3 種類の細胞から構成される. 中間・基底細 胞と, その隣にあるらせん勒帯の線維細胞は, ギャッ プジャンクションという「穴」で繋がっているため,

キーワード：内リンパ液高電位，蝸牛 $\mathrm{K}^{+}$イオン循環，らせん勒帯

1) 新潟大学大学院 医歯学総合研究科 分子生理学分野 (下951-8510 新潟市中央区旭町通 1 番町 757)

2) 九州大学大学院 医学研究院 耳鼻咽喉科・頭頸部外科学 ( ₹ 812-8582 福岡市東区馬出 3-1-1)

大阪大学大学院 医学系研究科 ${ }^{3)}$ 分子・細胞薬理学, ${ }^{4)}$ 耳鼻咽喉科・頭頸部外科学 ( $5565-0871$ 大阪府吹田市山田丘 2-2)

E-mail: nin@med.niigata-u.ac.jp＼cjkstart原稿受領日：2015 年 11 月 18 日, 依頼原稿

Title: Theoretical and experimental analysis of ototoxic mechanism in the spiral ligament fibrocytes by multi-level simulation with ion transports in the cochlea

Author: Fumiaki Nin, Takamasa Yoshida, Shingo Murakami, Satoru Uetsuka, Genki Ogata, Yoshihisa Kurachi, Hiroshi Hibino 
A

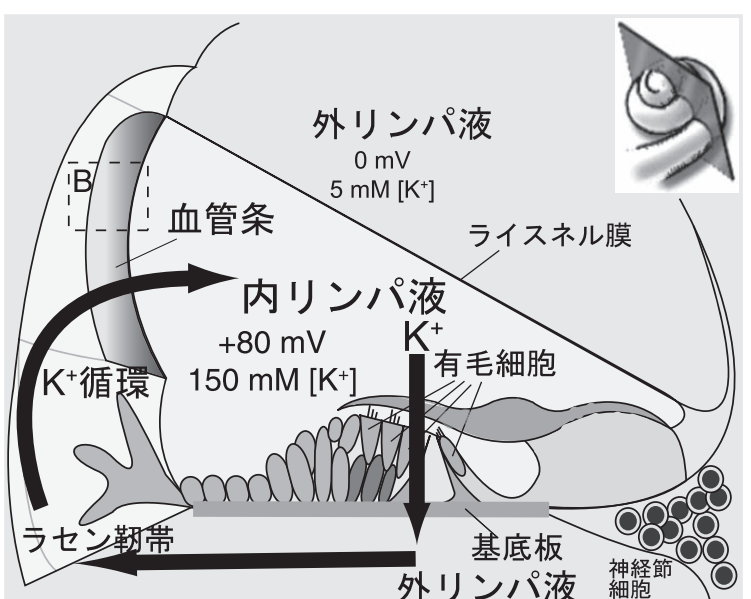

B

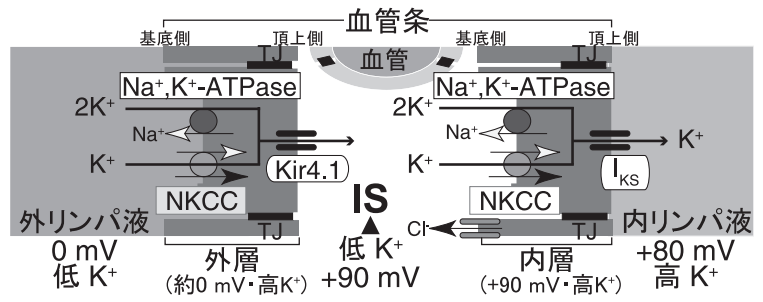

図 1 内耳蝸牛と血管条の構造

(A) 螖牛を縦切り (右上図)にした断面図. (B) 血管条の拡大図（点線 四角). $\mathrm{K}^{+}$循環・内リン八液高電位の維持に関わる血管条の輸送分子も 示す. 血管条は，機能的に内外二層から構成される. IS : intrastrial space, NKCC : $\mathrm{Na}^{+}, \mathrm{K}^{+}, 2 \mathrm{Cl}^{-}$共輸送体, TJ : タイトジャンクション. (文献 9 から改変)

全て等しい電位・イオン環境を示す合胞体と見なすこ とができる。また，辺縁細胞間と基底細胞間には，腎 臓や消化管の上皮と同じくタイトジャンクションとい うバリア構造が存在している，以上ょり，血管条は， 機能的に 2 つの上皮層, すなわち, 辺縁細胞からなる 内層と中間・基底・線維細胞からなる外層から構成さ れていると見なすことができる（図 1B)。本稿では便 宜的に線維細胞を外層とみなす。組織学的検討や, 薬 理学的・電気生理学的実験などから, 各層の基底側に は, $\mathrm{Na}^{+}, \mathrm{K}^{+}$-ATPase, $\mathrm{Na}^{+}, \mathrm{K}^{+}, 2 \mathrm{Cl}^{-}$共輸送体（NKCC） の $\mathrm{K}^{+}$イオン輸送体が, 頂上側には $\mathrm{K}^{+}$チャネル（外 層: Kir4.1, 内層 : $\mathrm{I}_{\mathrm{KS}}$ ）が分布していることが明らか になっている(2-6)（図 1B)。これらの輸送分子は, 内 リンパ液の電気・イオン環境に不可欠であり, それら の阻害薬は実際に難聴を引き起こすことが知られてい たが, 難聴の機序の多くが謎であった(2).

\section{2. 阻害薬が与える蝸牛内電位・イオン環境の 変化}

血管条の解剖学的特徵として, 以下の三つの点が挙 げられる。 (1)内層・外層・血管内皮細胞は, 各々が夕 イトジャンクションで繋がれ，これが血管条内部を 内・外リンパ液と血液から電気的に隔離している, (2)
このタイトジャンクションは，一般に上皮細胞の基底 膜側と頂上膜側の電気現象を隔離する働きがあるため, 血管条の電気動態は内・外層の基底・頂上膜の合計 4 つの膜区分に分けることができる, (3)内層の基底膜 と外層の頂上膜はひだ状で互いに絡み合い, それらに 挟まれた血管条細胞外空間（intrastrial space：IS）の 間隔は $15 \mathrm{~nm}$ と狭い（図 1B）(6). IS を満たす体液は, 通常の細胞外液と同じく $5 \mathrm{mM}$ 以下の $\mathrm{K}^{+}$イオン濃度 であるが, 内リンパ液の電位と同程度 $(\sim+90 \mathrm{mV})$ の 高電位を示す (図 1B) $(7,8)$ 。この intrastrial potential (IS 電位) と呼ばれる高電位は内リンパ液高電位の源 であるとされ，その動態が $\mathrm{EP} に 反$ 映する(9).

我々はまず, 阻害薬が血管条内部の電位・イオン環 境に与える変化を測定するため, $\mathrm{K}^{+}$選択的イオン電 極 $\left(\mathrm{K}^{+}\right.$電極 $)$をルモット血管条の細胞内外の各微小 区域に扦入し, 一方で, 動脈経由で $\mathrm{K}^{+}$イオン輸送体 の阻害薬を生動物に投与した $(9)$. 図 2 は, $\mathrm{K}^{+}$電極を 外リンパ液から血管条へと進めた際の電位（黒線）と $\mathrm{K}^{+}$イオン濃度（灰色線）の変化を示したものである. 生理実験における濃度は, 実効值である活量という単 位で表しているため, 一般的な濃度の值より低く示さ れる. 外リンパ液 $\left(0 \mathrm{mV}\right.$ ・低 $\left.\mathrm{K}^{+}\right)$より $\mathrm{K}^{+}$電極を進め ると, 最初に $\mathrm{K}^{+}$イオン濃度 ( $\mathrm{K}^{+}$活量) が $65 \sim 85 \mathrm{mM}$ と高く, 電位が $+2 \sim 3 \mathrm{mV}$ と正の值を示す地点（黒矢 印）を見出した。解剖学的に, これは外層 (線維細胞) （図 1B）を観察していると考えられた。ささらに電極を 進めると, 電位が $+70 \mathrm{mV}$ と高く, $\mathrm{K}^{+}$イオン濃度が $4 \mathrm{mM}$ と低い IS 部位を認めた (白矢印). 無酸素負荷や ウアバイン投与により血管条内層の $\mathrm{Na}^{+}, \mathrm{K}^{+}$-ATPase を 阻害したところ, IS 電位は無酸素負荷時には+70 mV から+22 mVへと下降し, $\mathrm{K}^{+}$イオン濃度は $4 \mathrm{mM}$ から

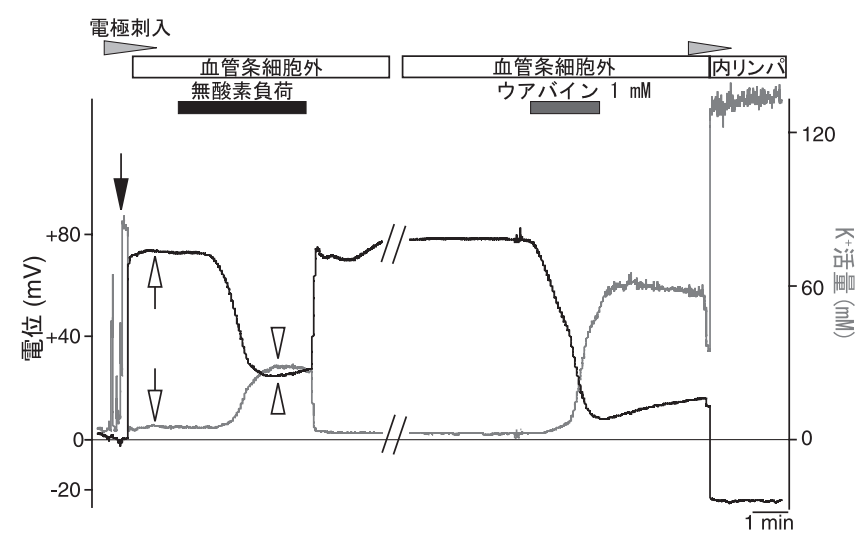

図 2 内層 $\mathrm{Na}^{+}, \mathrm{K}^{+}$-ATPase 阻害の効果 $\mathrm{K}^{+}$電極による血管条の各区分の $\mathrm{K}^{+}$イオン濃度と電位の測定. 黒線は電 位を, 灰色線は $\mathrm{K}^{+}$イオン濃度 (活量) の变化を示す. 無酸素負荷およ びウアバインの潅流で内層の $\mathrm{Na}^{+}, \mathrm{K}^{+}$-ATPase を阻害した。（文献 9 か ら改変) 
$28 \mathrm{mM}$ へと上昇する変化を認めた (白矢頭)。ウアバイ ン投与時には，この変化は不可逆的かつより大きく変化 した．また，NKCCの阻害薬であるブメタニドも，無 酸素負荷やウアバイン投与時とほぼ同じ効果を呈した。

次に, 外層（線維細胞）においてどのような電位・ $\mathrm{K}^{+}$イオン濃度変化が起きるかを検討するため, $\mathrm{K}^{+}$電 極を線維細胞内に挿入すると同時に, 経外リンパ液経 由で阻害薬を生動物に投与した。線維細胞は細胞体が 小さいため, 細胞内電位と $\mathrm{K}^{+}$イオン濃度を持続的に 計測することは困難である。そこで，ガラス電極を内 リンパ液内に留置して電位を計測しつつ，一方でイオ ン電極を複数回外層へ刺入した，イオン電極刺入時に 一過性に計測される高い $\mathrm{K}^{+}$イオン濃度を示す部位が 線維細胞内であり, この時の電位を線維細胞膜電位と 見なす (10)。内リンパ液の電位をモニターしながら (図 3Ad), 正常状態において $\mathrm{K}^{+}$電極を外リンパ液か ら進めると（図 $3 \mathrm{Aa}$ ), 数 $\mathrm{mV}$ の電位のままで $\mathrm{K}^{+}$イオン 濃度が約 $80 \mathrm{mM}$ と高くなる点を見出した（図 $3 \mathrm{Aa} ：$ 黒 丸)。ウアバインを外リンパ液に潅流し $\mathrm{Na}^{+}, \mathrm{K}^{+}$-ATPase を阻害している間に, 線維細胞の電位・ $\mathrm{K}^{+}$イオン濃 度を複数回計測すると, 電位はほとんど変化が見られ ないのに対し, $\mathrm{K}^{+}$イオン濃度は経時的に $10 \mathrm{mM}$ 以下 まで低下することが計測された（図 3Ab，c：黑丸）(10).

同様に，今度はブメタニドを外リンパ液に潅流して
$\mathrm{NKCC}$ を阻害し，この時の線維細胞の電位・ $\mathrm{K}^{+}$イオ ン濃度を計測すると, 共に変化がなかったが（図 $3 \mathrm{~B}$ ： 黒丸), 意外なことに IS の電位の低下と $\mathrm{K}^{+}$濃度の上昇 が見られた (図 3B：黑矢頭) (11)。これは，ブメタニド を動脈経由で動物に投与した時と同様の変化であった。

\section{3. 蝸牛 $\mathrm{K}^{+}$循環数理モデルの改訂}

イオン輸送体に依存して変化する膜電位と膜を介し た電流の動態は, 等価電気回路として表現できる. 我々はこれまでに, 各膜上の輸送分子を等価電気回路 として示し, 有毛細胞を電球, 内リンパ液高電位を電 池， $\mathrm{K}^{+}$循環を電流とみなした血管条の $\mathrm{K}^{+}$イオン輸送 と蝸牛の $\mathrm{K}^{+}$循環を再現する数理モデル Nin-HibinoKurachi (NHK) model を構築し(図 4A), 動脈経由で 阻害薬を投与した際の電位・ $\mathrm{K}^{+}$イオン濃度動態の再 現に成功した（図 4B）(12).

そこで, 図 3 の実験結果に基づいて, 線維細胞膜に 発現するイオン輸送体を設定し, 既存の蝸牛 $\mathrm{K}^{+}$循環 数理モデルを改訂した（図 5). 新規数理モデルでは, 線維細胞膜において $\mathrm{Na}^{+}, \mathrm{K}^{+}$-ATPase が輸送する $\mathrm{Na}^{+}$ イオンを局所でリサイクルする $\mathrm{Na}^{+}$選択性（電流）イ オンチャネルを仮定し, $\mathrm{Na}^{+}, \mathrm{K}^{+}$-ATPase が IS 方向へ $\mathrm{K}^{+}$イオンを輸送できるよう設定する. 図 3 に示した 無酸素負荷時に見られた電位・ $\mathrm{K}^{+}$イオン濃度の変化

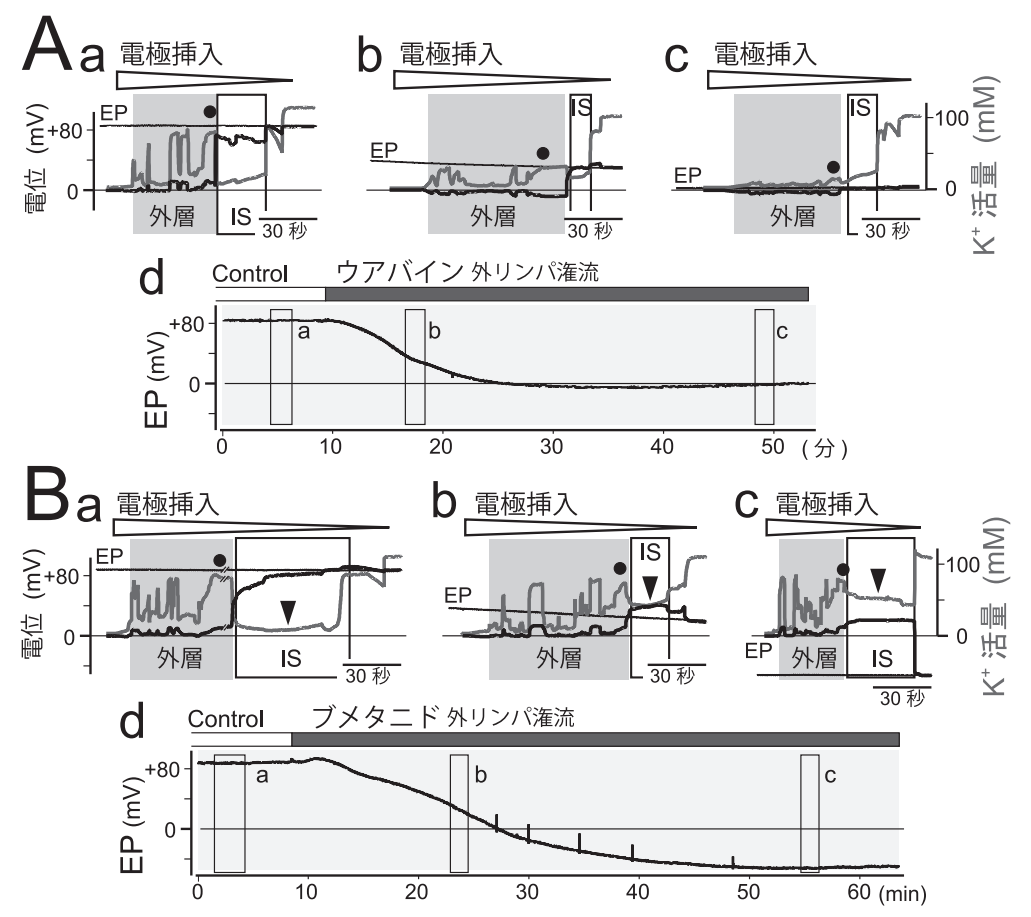

図 3 外層（線維細胞） $\mathrm{Na}^{+}, \mathrm{K}^{+}$-ATPase および NKCC 阻害の効果

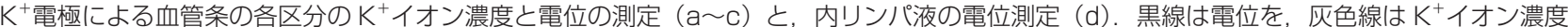
（活量）の变化を示す。（A）ウアバインの潅流で線維細胞の $\mathrm{Na}^{+}, \mathrm{K}^{+}$-ATPase を阻害すると, 線維細胞内の $\mathrm{K}^{+}$イオン濃度は徐々に低下を示し た. (B) ブメタニドの潅流で線維細胞の NKCC を阻害しても, 線維細胞内の $K^{+}$イオン濃度はほとんど变化しない. 一方で, ISにおける $K^{+} イ$ オン濃度が上昇している.（文献 10, 11 から改変） 
A

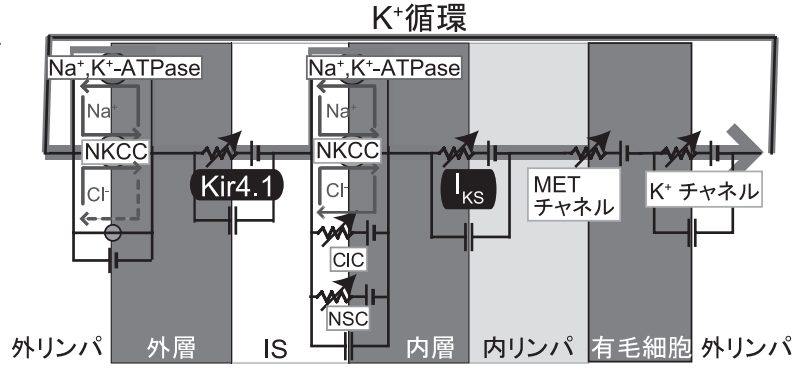

B a
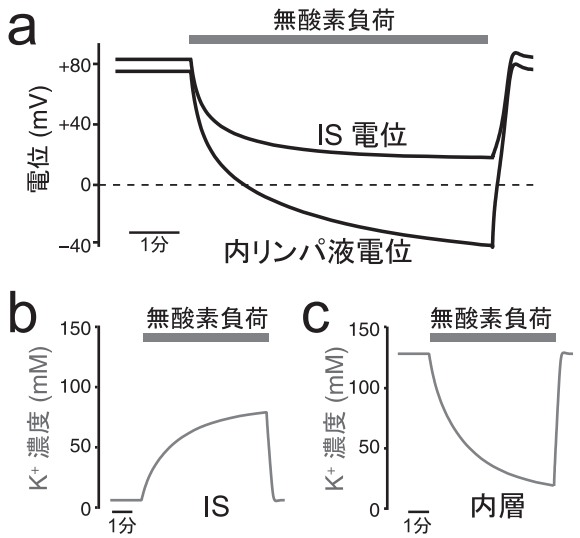

図 4 数理モデル (NHK model) による蝸牛 $\mathrm{K}^{+}$循環のシミュレー ション

(A) 血管条 $K^{+}$輸送と蝸牛 $K^{+}$循環を表す等価電気回路. NKCC : $\mathrm{Na}^{+}, \mathrm{K}^{+}, 2 \mathrm{Cl}^{-}$共輸送体, $\mathrm{ClC} ： \mathrm{Cl}^{-}$チャネル, NSC : 非選択性陽イオン チャネル, MET：機械刺激感受性チャネル.（B）正常時および無酸素 負荷時における各区分の電位 $\left(a ：\right.$ 黒線) と $\mathrm{K}^{+}$イオン濃度 $(\mathrm{b}, \mathrm{c}$ ：灰色 線）の経時的変化. なお, 濃度は活量でない.（文献 12 から改変）

を，今後新しい数理モデルを用いたシミュレーション によって再現を試みる予定である.

\section{4. おわりに}

数理モデルに設定する $\mathrm{Na}^{+}$選択性イオンチャネルと は，一体どのような分子なのであろうか。これまでに， 上皮性 $\mathrm{Na}^{+}$チャネル $(\mathrm{ENaC})$ が線維細胞に発現して いることが報告されているが，その阻害薬であるアミ ロライドの潅流実験では内リンパ液高電位に影響がな い $(13,14)$. その他, 薬理学的に検証可能な $\mathrm{Na}^{+}$チャ ネルの関与も現在否定的である. しかしここに, 数理 モデルによって薬剤の有無に捉われずに予測を立てる 大きな意義があると考える，今後，より詳細に数理モ デルのパラメータを設定し, 実験結果を精密に再現で きるようアップデートが行えれば，様々な病態を理論 的に抽出することも可能となるであろう. 未知のイオ

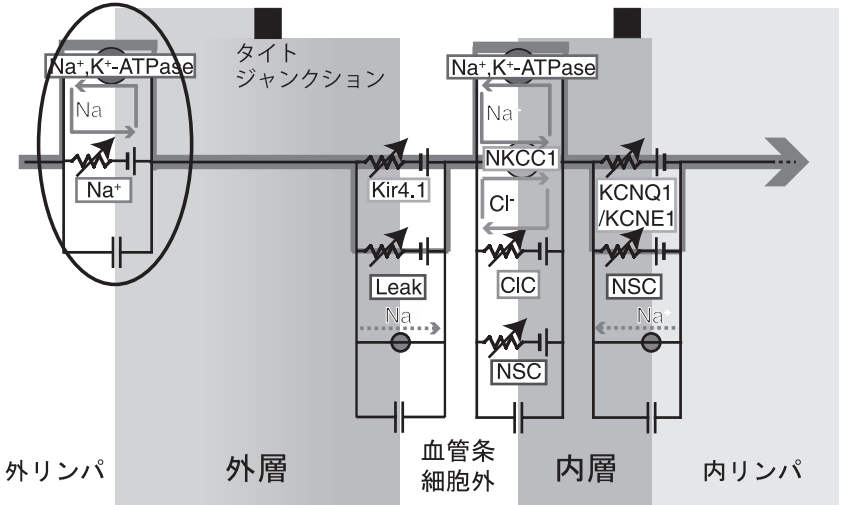

図 5 改訂数理モデルにおける線維細胞の設定

外層（線維細胞）部を改訂した新規等価電気回路. $\mathrm{Na}^{+}: \mathrm{Na}^{+}$選択性 (電流) チャネル.

ンチャネルやその他線維細胞に関わる分子の候補探索 には，近年報告がなされつつあるタンパク質の網羅的 解析法による研究成果も今後大きく寄与するであろう (15). 将来的に原因不明の聴覚疾患の病因究明や難聴 に対する新しい治療法の開発を進めるには，今回のよ うに実験と計算科学を相補的にフィードバックさせる 研究手法が極めて有効であると考える.

謝辞: 本研究の遂行にあたり, 支援を賜った実験助手の堀 かりん様に感謝いたします。また，第 24 回日本薬理学会総 会のセミナーにおいて講演する機会を与えてくださった オーガナイザーの京都大学の山下富義教授, 本稿を作成す る機会を与えてくださった編集部の方々に深謝申し上げます。

著者の利益相反：開示すべき利益相反はない.

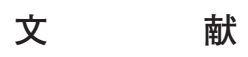

1) Bekesy G. J Acoust Soc Am. 1952;24:72-76.

2) Kusakari J, et al. Laryngoscope. 1978;88:12-37.

3) Marcus DC, et al. Hear Res. 1985;17:79-86.

4) Sakagami M, et al. Hear Res. 1991;56:168-172.

5) Ando M, et al. Cell Tissue Res. 1999;298:179-183.

6) Hibino H, et al. Physiology (Bethesda). 2006;21:336-345.

7) Salt AN, et al. Laryngoscope. 1987;97:984-991.

8) Ikeda K, et al. Hear Res. 1989;40:111-116.

9) Nin F, et al. Proc Natl Acad Sci U S A. 2008;105:1751-1756.

10) Adachi N, et al. J Physiol. 2013;591:4459-4472.

11) Yoshida T, et al. Pfluger Arch. 2015;467:1577-1589.

12) Nin F, et al. Proc Natl Acad Sci U S A. 2012;109:9191-9196.

13) Couloigner V, et al. Am J Physiol Renal Physiol. 2001;280:F214-F222

14) Salt AN, et al. Jpn J Physiol. 1982;32:219-230.

15) Uetsuka S, et al. Eur J Neurosci. 2015;42:1984-2002. 